\title{
Morphological and molecular study of epipelic filamentous genera Phormidium, Microcoleus and Geitlerinema (Oscillatoriales, Cyanophyta/ Cyanobacteria)
}

\author{
Petr HaŠLeR ${ }^{1 *}$, Petr DvořÁK ${ }^{1}$, Jeffrey R. JohanSEN ${ }^{2}$, Miloslav Kitner ${ }^{1}$, Vladan \\ ONDŘEJ ${ }^{1} \&$ Aloisie POULÍČKOVÁ ${ }^{1}$ \\ ${ }^{1}$ Department of Botany, Faculty of Science, Šlechtitelu 11, CZ-783 71 Olomouc, Czech Republic; *Corresponding \\ authore-mail:petr.hasler@upol.cz \\ ${ }^{2}$ Department of Biology, John Carroll University, 20700 North Park Blvd., University Heights, Ohio 44118, USA
}

\begin{abstract}
Filamentous epipelic cyanobacteria were isolated from ponds and lakes in the Czech Republic, Austria and Italy. Morphological and genetic variation of 20 isolated strains within the genera Geitlerinema, Microcoleus and Phormidium were studied. Partial sequences of the 16S rRNA gene were used for phylogenetic analyses, and secondary structure of the $16 \mathrm{~S}-23 \mathrm{~S}$ ITS region was used to additionally define clades. Morphological and molecular were congruent, and we were able to identify the majority of strains correctly to species on the basis of morphological features. Overall diversity and morphological/genetic variation of epipelic species is not as high as described from other benthic habitats, possibly due to the relative microhabitat uniformity of lake/pond bottom sediments. The M. vaginatus clade is well defined by an 11 bp insert in 16S rRNA gene (bp 423-433) and populations from different ecological conditions differ in secondary structure in the 16S-23S ITS regions, particularly in Box-B helices. Ph. autumnale and the genus Geitlerinema appear to be polyphyletic as presently defined.
\end{abstract}

Key words: $16 \mathrm{~S}$ rRNA, cyanobacteria, ecology, ITS, morphology, phylogeny, Oscillatoriales

\section{Introduction}

During most of the $19^{\text {th }}$ and $20^{\text {th }}$ centuries cyanobacterial taxonomy was based almost entirely on morphology (GEITLER 1932; ELENKIN 1938; Desikachary 1959; Starmach 1966; KONDRATEVA 1968). The taxonomic position of many morphologically-defined species is unclear and some genera urgently need revision (e.g. KomÁreK \& ANAGNOSTIDIS 1998; KomÁreK \& ANAGNOSTIDIS 2005). Moreover, the situation is complicated by a conflict between bacteriological and botanical nomenclatural rules and taxonomic practices (STANIER et al. 1978; RIPPKA et al. 1979; Castenholz 2001). The most progressive system utilizes a polyphasic approach (ANAGNOSTIDIS \& KOMÁREK 1985; KOMÁREK \& ANAGNOSTIDIS 1986; ANAGNOStidis \& KomÁreK 1988; KomÁreK \& ANAGNOSTIDIS 1989; ANAGNostidis \& KomÁREK 1990; KoMÁreK 1994, 2003; КоMÁreK 2011), which includes a combination of morphological, ecological and molecular character sets. Recent molecular data support the validity of many genera, e.g. Planktothrix, Pseudananabaena (Willame et al. 2006), Microcystis, and Spirulina (KomÁrek 2003, 2010) as defined by KomÁreK \& Anagnostidis $(1998,2005)$, but at the species level we often have insufficient morphological, ecological and molecular data for reliable recognition of species-level diversity. In recent years, the analysis of the $16 \mathrm{~S}$ rRNA gene sequences has demonstrated that morphological classification of cyanobacteria in some cases corresponds to phylogenetically coherent taxa (GARCiA-Pichel et al. 1996), whereas in other cases the traditional classification drastically underestimates extant diversity (FERRIs et al. 1996).

The assemblages of autotrophic microoranisms (cyanobacteria, algae) on bottom sediments of stagnant and running waters are called epipelon. These microorganisms perform a range of ecosystem functions including biostabilisation of sediments, regulation of 
benthic-pelagic nutrient cycling, and primary production (PoulíčKová et al. 2008a). Although epipelic eukaryotic algae were previously studied, e.g. diatoms (reproductive biology, cryptic speciation, geographic biodiversity and bioindication; PoulíčKovÁ et al. 2008a, 2008b, 2009), epipelic cyanobacteria have been largely overlooked. The ecology of epipelic cyanobacteria is poorly understood. Species distribution is probably influenced by numerous environmental variables such as temperature, light irradiation, oxygen concentration, $\mathrm{pH}$, sediment structure and chemical composition (e.g. Round 1953, 1957, 1961; HAŠLER et al. 2008). Autochthonous epipelic assemblages typically include $20-80 \%$ filamentous motile cyanobacteria during some seasons of the year, particularly Komvophoron, Oscillatoria, Phormidium, Geitlerinema and Pseudanabaena (ŠPAČKOVÁ et al. 2009; HAŠLER \& PoulíčKovÁ 2010).

We isolated 20 strains of filamentous epipelic cyanobacteria from ponds and lakes of different trophic status in three EU countries (Czech Republic, Austria and Italy). This project aims at taxonomic evaluation of the epipelic filamentous cyanobacteria (Geilterinema, Microcoleus and Phormidium) based on morphological and molecular characters.

\section{Materials and Methods}

Strain isolation and morphological study. Altogether 48 sediment samples were taken during May 2007 using methods described by HAŠLER et al. (2008). The geographic position and environmental variables of the Czech sites were published by HAŠLER et al. (2008). Italian localities (Monbino, GPS: 46' $28.191^{\prime \prime N}$,

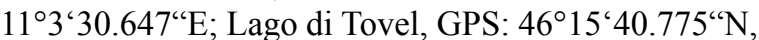
$10^{\circ} 56^{\circ} 57.851^{\circ \mathrm{E})}$ were situated in Trento, near the border between Italy and Austria. The locality in Austria (Untersee) is situated at Lunz am See (GPS: $47^{\circ} 51^{\prime} 11.602^{\prime \prime} \mathrm{N}, 15^{\circ} 3^{\prime} 3.256^{\prime \prime} \mathrm{E}$ ), southwest of Vienna. Strains of filamentous morphospecies were isolated following standard methods (ANDERSEN et al. 2005). Cultures were maintained in $100 \mathrm{ml}$ Erlenmeyer flasks under our standard laboratory conditions (temperature $22 \pm 1{ }^{\circ} \mathrm{C}$, illumination $20 \mathrm{mmol} \cdot \mathrm{m}^{-2} \cdot \mathrm{s}^{-1}$, light regime $12 \mathrm{~h}$ light $/ 12 \mathrm{~h}$ dark, liquid Zehnder medium (STAUB 1961). All strains were studied using a Zeiss AxioImager light microscope (objectives EC PlanNeofluar $40 \times / 1.3$ N.A., oil immersion, DIC; PlanApochromat $100 \times / 1.4$ N.A., oil immersion, DIC); with images taken with a high resolution camera (AxioCam HRc 13MPx). During morphological evaluation we focused on these characters: trichome shape and width, presence of sheath, cell dimensions, cell wall constrictions, shape of apical cell, presence or absence of calyptra, and granulation of cells. At least 30 filaments of each strain were characterized.

DNA extraction. DNA extraction was performed using the protocol of Doyle \& DOyle (1990). The integrity and quality of DNA was checked on $1.8 \%$ agarose gels. Concentrations of DNA samples were assessed using a NanoDrop ND-1000 Spectrophotometer (NanoDrop Technologies, Delaware, USA).

DNAamplification and sequencing. PCR amplification of the partial $16 \mathrm{~S}$ rRNA gene and full $16 \mathrm{~S}-23 \mathrm{~S}$ ITS region was performed using a combination of two primers P1 (5'-CTCTGTGTGCCTAGGTATCC-3') and P2 (5'-GGGGAATTTTCCGCAATGGG-3') described previously in BOYER et al. (2002). These primers produce a $\sim 1180$ bp segment of the $16 \mathrm{~S}$ rRNA gene (bp 325-end) as well as the complete 16S-23S ITS region and 30 bases of the $23 \mathrm{~S}$ rRNA gene. Total volume of the PCR reaction was $20 \mu \mathrm{l}$ and it contained: $8.5 \mu \mathrm{l}$ of sterile water, $0.5 \mu \mathrm{l}$ of each primer (concentration $0.01 \mathrm{mM}$ ), $10 \mu \mathrm{l}$ FastStart PCR master (Roche Diagnostics GmbH, Mannheim, Germany) and $0.5 \mu \mathrm{l}$ of template DNA $\left(50 \mathrm{ng} \cdot \mu \mathrm{l}^{-1}\right)$. Conditions of the PCR reaction were: 1) initial denaturation for 4 min at $95{ }^{\circ} \mathrm{C}$, 2) 35 cycles of denaturation for $30 \mathrm{~s}$ at $95^{\circ} \mathrm{C}$, annealing for $30 \mathrm{~s}$ at $57^{\circ} \mathrm{C}$, and extension for 1 min $50 \mathrm{~s}$ at $72{ }^{\circ} \mathrm{C}$, and 3) a final extension for $7 \mathrm{~min}$ at $72{ }^{\circ} \mathrm{C}$. PCR product was checked on $1.5 \%$ agarose gels stained with ethidium bromide. Finally, PCR product was purified using GenElute ${ }^{\mathrm{TM}}$ PCRClean-Up Kit (Sigma-Aldrich, Co., Saint Louis, Mo, USA) and sent away for commercial sequencing. Sequencing primers were same as primers for amplification.

Phylogenetic analyses. The sequences were assembled in BioEdit v 7.0.5 (HALl 2005) and gene sequence anomalies (e.g. chimeras) were detected using Mallard software (ASHELFORD et al. 2005). All sequences investigated in this study were deposited in GenBank (see accession numbers in Table 1). Additional sequences for further phylogenetic analysis were acquired from GenBank (http://www. ncbi.nlm.nih.gov/) using the following criteria: sequences had to be sufficiently long (at least 1013 bp) and freshwater species of Oscillatoriales sensu lato (Pseudanabaenales, Phormidiales, Oscillatoriales in newer taxonomy). Moreover, we tried to avoid poorly determined sequences (marked with sp.). Using these criteria, 78 sequences were chosen for analysis, a data set that was as large as possible given the time restraints of the phylogenetic analyses used. All sequences were initially aligned in Clustal X (LARKIN et al. 2007) and manually corrected in BioEdit version 7.0.5 (HALL 2005). Gloeobacter violaceus PCC 8105 was selected 
as the outgroup taxon.

Phylogenetic analysis was carried out in Mr. Bayes 3.1 (RonQuist \& HuELSENBECK 2003), PAUP* version 4.0b10 (SwOFFORD 2001) and MEGA 5.02 (TAMURA et al. 2007). Evolutionary models were selected on the basis of the BIC (Bayesian Information Criterion) model test implemented in MEGA 5.02. The evolutionary model used in Mr. Bayes was the GTR model with gamma-distributed rate variation across sites and a proportion of invariable sites. The analysis was run for 10000000 generations with sampling every $100^{\text {th }}$ generation. Minimum evolution (ME) and maximum likelihood (ML) analyses were performed in MEGA 5.02 and maximum parsimony (MP) in PAUP*, gaps were treated as missing data. GTR $+\Gamma$ model was used in $\mathrm{ML}$ analysis. Bootstrap resampling was performed using 1000 replications (ME, MP) or 500 replications (ML), respectively.

The secondary structures of different ITS regions (D1-D1' helix and Box-B helix) were predicted with the Mfold web server version 3.2 (ZUCKER 2003) with temperature set to default conditions $\left(37^{\circ} \mathrm{C}\right)$ and draw mode at untangle with loop fix. Secondary structures were then drawn in Adobe Illustrator (CS-3).

\section{Results}

\section{Morphology of investigated strains}

Morphological variability was studied in natural samples as well as in isolated strains. We did not observe extensive variability in filaments in studied morphospecies, especially in natural samples (Table 1). All strains produced singletrichome filaments, only seldom forming filaments of up to five trichomes (e.g. typical for $M$. vaginatus). Isolated strains usually formed fine mats (Phormidium, Geitlerinema carotinosum, $G$. pseudoacutissimum), macroscopic/microscopic fasciculated colonies ( $M$. vaginatus, G. carotinosum, G. pseudacutissimum) or spherical colonies ( $G$. splendidum). $M$. vaginatus often loses its fasciculated filaments in culture, and is then morphologically difficult to separate from $\mathrm{Ph}$. autumnale given the similarities in cell dimensions, type of cell division, absence of constrictions at cross-walls, and presence of tapering and calyptra in mature trichomes. However, M. vaginatus (Figs 1-8) was distinguishable from $P h$. autumnale (Figs 9-20) in the frequent presence of conspicuous granules at the cross-walls and generally wider trichomes. Trichomes of Ph. formosum (Figs 21-27) were intensely motile (gliding, rotating), constricted slightly at cross-walls, tapered towards apices which possessed rounded to rounded-conical apical cells lacking calyptra. Granulation was fine, if present. A strain of G. carotinosum (P013, Fig. 33) was isolated from Lunzer Untersee, from the same watershed as Geitler's type material (Lunzer Untersee is hydrologically connected with the type locality Lunzer Obersee, Austria). Apical cells were rounded and conspicuous carotenoid granules were present at cross-walls in this strain. G. pseudacutissimum (Figs 28-32) contained fine carotenoid granules at cross-walls but to a lesser extent than in $G$. carotinosum. Apical cells were hooked or rounded-acuminate. Both strains of G. splendidum (Figs 34-39) did not differ from each other. They both possessed intensely motile attenuated trichomes, and were bent or screw-like at the ends with capitate or rounded apical cells.

\section{Analysis of 16S rRNA and secondary structures of ITS}

The PCR reactions yielded a partial 16S rRNA gene (size $\sim 1100$ bp) from every strain. Phylogenetic analysis included also comparable long sequences available in GenBank, particularly well defined freshwater strains of filamentous cyanobacteria (Fig. 40) from the families Pseudanabaenaceae, Phormidiaceae and Oscillatoriaceae. Positions of isolated species in the consensus Bayesian tree were in good agreement with their morphology. The Phormidiaceae formed a distinct clade, but members of the Pseudanabaenaceae formed a paraphyletic cline below the Phormidiaceae (Fig. 40). This made clear separation of Pseudanabaenaceae from the Phormidiaceae difficult.

M. vaginatus, as defined by both morphology and the 11 bp insert (bp 423-433), formed a distinct well-supported clade (Fig. 40, clade A). A single filamentous strain identified initially as $P h$. autumnale P007 due to its slightly narrower trichome diameter had the $11 \mathrm{bp}$ insert as well and was subsequently redesignated $M$. vaginatus. Three strains of $P h$. autumnale in clade A (strains EU196619-21) had the same 11 bp insert and were isolated from puddles in the Czech Republic by other workers (LoKMER 2007). We conclude that they belong to $M$. vaginatus, and should be considered as such in future studies. All strains in this clade were $98 \%$ or more similar in their 16S rRNA gene sequence similarity.

Phormidum autumnale sensu stricto (lacking the $11 \mathrm{bp}$ insert) fell into two lineages sister to M. vaginatus, and included a GenBank 


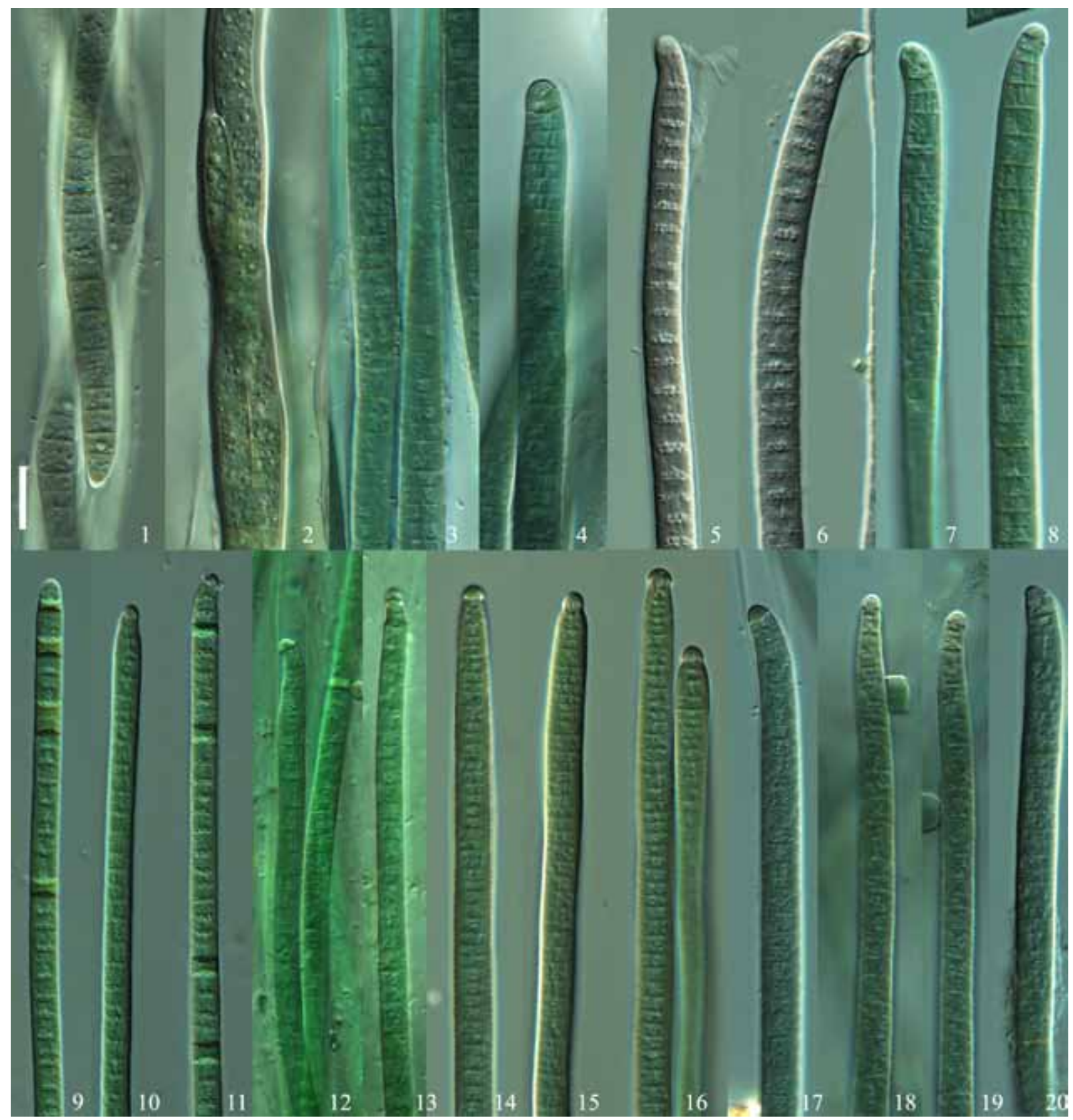

Figs 1-20. Variability of filamentous epipelic cyanobacteria: (1-2) M. vaginatus, strain P006; (3-4) M. vaginatus, strain P0R1; (5-6) M. vaginatus, strain P09; (7) M. vaginatus, strain P0B; (8) M. vaginatus, strain P0C; (9-11) Ph. autumnale, strain P00; (12-13) M. vaginatus, strain P007; (14-16) Ph. autumnale, strain P019; (17-20) Ph. autumnale, strain P012. Scale bar $10 \mathrm{~mm}$.

sequence designated as Phormidium cf. subfuscum. The branch of $P h$. autumnale including $P h$. cf. subfuscum did not have good support. However, the clade with clearly calyptrate taxa (Fig. 40, clade B) had good bootstrap support. Oscillatoria sancta and Oscillatoria cf. curviceps do not have the capitate apices with calyptra, but both can have a thickened end cap which has been interpreted to be a calyptra (KOMÁReK \& ANAGNOSTIDIS 2005). The clade that includes these two Oscillatoria and clade B, (Ph. autumnale and M. vaginatus) is also well supported.
The clade of $P h$. formosum had high bootstrap support and 16S rRNA sequence data showed at least two lineages corresponding to their geographic origin. Both lineages had high bootstrap support.

The branch containing the calyptrate taxa and non-calyptrate Phormidium, along with a mixture of taxa including some Geitlerinema, Microcoleus, Coleofasciculus, Wilmottia and Phormidium species had good bootstrap support (Fig. 40, clade C).

Analysis of the 16S rRNA gene separated 


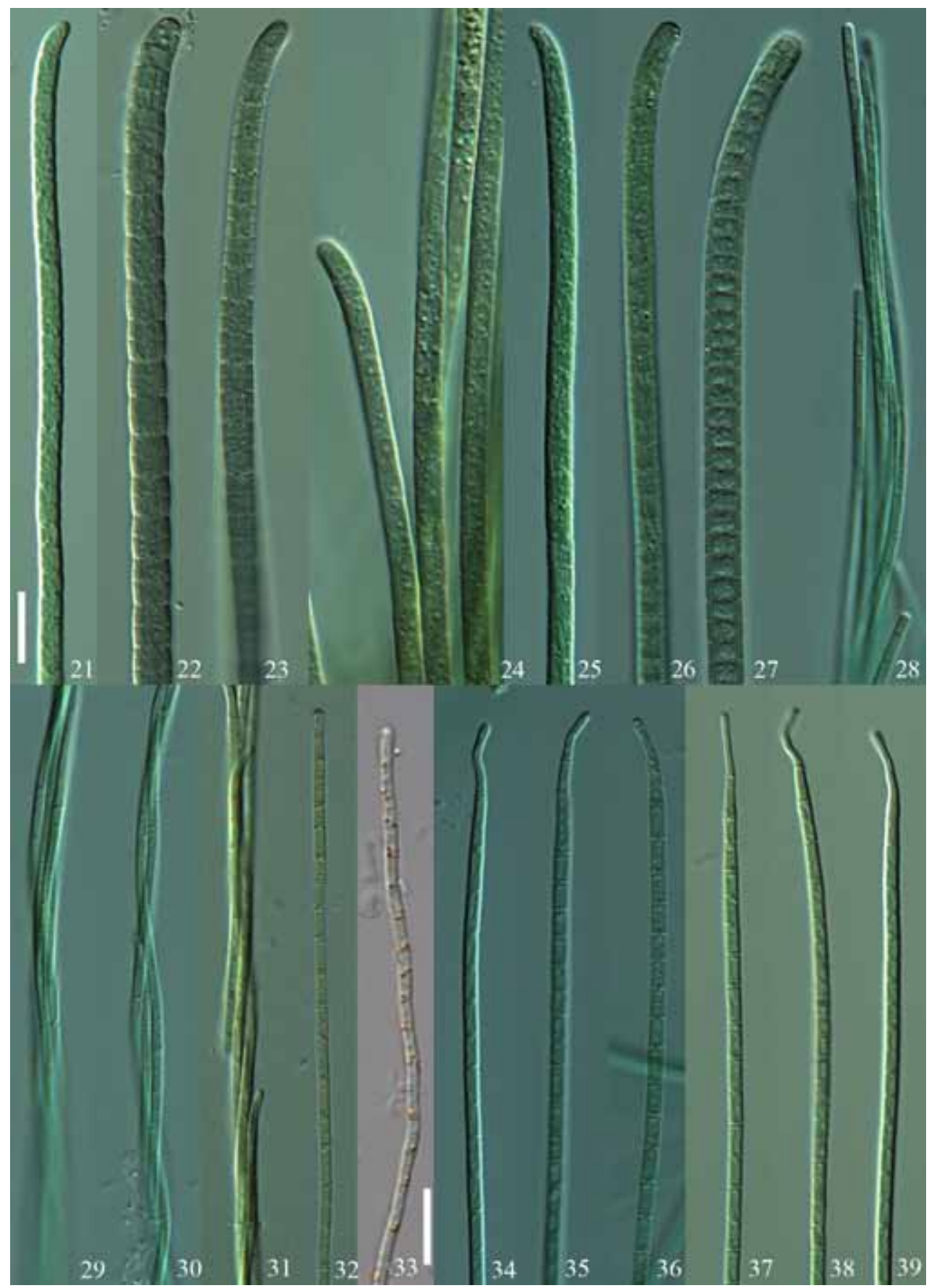

Figs 21-39. Variability of filamentous epipelic cyanobacteria: (21) Ph. formosum, strain P0010; (22-23) Ph. formosum, strain P07; (24) Ph. formosum, strain P0A; (25) Ph. formosum, strain P001; (26-27) Ph. formosum, strain P010; (28) G. pseudacutissimum, strain P03; (29-30) G. pseudacutissimum, strain P004; (31-32) G. pseudacutissimum, strain P005; (33) G. carotinosum, strain P013; (34-36) G. splendidum, strain P014; (37-39) G. splendidum, strain P017. Scale bars 10 mm [(21-32, 34-39), (33)].

G. carotinosum P013 (Austria) from morphologically similar strains of G. pseudacutissimum originating from Italian Lakes Tovel and Monbino (Italy). The internal sequence similarity of the 16S rRNA gene in the G. pseudoacutissimum clade was $98.6-99.4 \%$ (Fig. 40, clade D). $G$. carotinosum had very low similarity to the taxa we place in G. pseudoacutissimum (including
"G. carotinosum" AICB 37), with 16S rRNA similarity to each of those strains ranging 93.1$93.6 \%$ similar. G. splendidum formed a separate clade, which was strongly supported, although our two strains shared only $97.0 \%$ similarity. All our strains of Geitlerinema were more related to Phormidiaceae than to Pseudanabaenaceae. Geitlerinema sequenced by others were clearly 
Table 1. List of isolated strains of epipelic filamentous cyanobacteria [morphology: (L/W) length width ratio, (C) calyptra, (S) sheath, $n=30$; origin: (A) Austria, (CZ) Czech Republic, (I) Italy]. Molecular characteristics of isolated strains [length of 16S rRNA for all strains $\sim 1031 \mathrm{bp}$; Gen Bank access number (16S rRNA+ITS), genes of tRNA ${ }^{\text {Ala }}$ and tRNA ${ }^{\text {Ile }}$ in all strains]. Measured environmental variables are shown in Hašler et al. (2008).

\begin{tabular}{|c|c|c|c|c|c|c|c|c|c|}
\hline Strain & $\begin{array}{l}\text { Trichome } \\
\text { end }\end{array}$ & Apical cell & $\begin{array}{l}\text { Width } \\
\text { mm }\end{array}$ & $\begin{array}{l}\text { Cell } \\
\mathrm{L} / \mathrm{W}\end{array}$ & $\mathrm{C}$ & $\mathrm{S}$ & $\begin{array}{l}\text { GenBank } \\
\text { access num- } \\
\text { ber }\end{array}$ & $\begin{array}{l}\text { ITS } \\
\text { length }\end{array}$ & Origin \\
\hline \multicolumn{10}{|c|}{ Ph. autumnale } \\
\hline P00 & Attenuated & $\begin{array}{l}\text { Rounded, } \\
\text { conical, } \\
\text { capitate }\end{array}$ & $4-6$ & $0.3-1$ & + & + & $\begin{array}{l}\text { JQ712616 } \\
\text { JQ347244 }\end{array}$ & 560 & $\begin{array}{l}\mathrm{CZ} \\
\text { Obectov }\end{array}$ \\
\hline P012 & Attenuated & $\begin{array}{l}\text { Rounded, } \\
\text { conical, } \\
\text { capitate }\end{array}$ & $5-7$ & $0.5-1$ & + & + & $\begin{array}{l}\text { JQ712612 } \\
\text { JQ347240 }\end{array}$ & 556 & $\begin{array}{l}\text { CZ } \\
\text { Chropyně }\end{array}$ \\
\hline P007 & Attenuated & $\begin{array}{l}\text { Rounded, } \\
\text { conical, } \\
\text { capitate }\end{array}$ & $4-5$ & $0.5-1$ & + & + & $\begin{array}{l}\text { JQ712604 } \\
\text { JQ347232 }\end{array}$ & 547 & $\begin{array}{l}\mathrm{CZ} \\
\text { Vrah }\end{array}$ \\
\hline P019 & Attenuated & $\begin{array}{l}\text { Rounded, } \\
\text { conical, } \\
\text { capitate }\end{array}$ & $4-6$ & $0.3-0.75$ & + & + & $\begin{array}{l}\text { JQ712607 } \\
\text { JQ347235 }\end{array}$ & 525 & $\begin{array}{l}\text { CZ } \\
\text { Buková }\end{array}$ \\
\hline \multicolumn{10}{|c|}{ Ph. formosum } \\
\hline P0010 & $\begin{array}{l}\text { Shortly } \\
\text { attenuated }\end{array}$ & $\begin{array}{l}\text { Rounded, } \\
\text { conical }\end{array}$ & $4-5$ & $0.5-1$ & - & - & $\begin{array}{l}\text { JQ712600 } \\
\text { JQ347228 }\end{array}$ & 645 & $\begin{array}{l}\mathrm{CZ} \\
\text { Naděje }\end{array}$ \\
\hline P07 & $\begin{array}{l}\text { Shortly } \\
\text { attenuated }\end{array}$ & $\begin{array}{l}\text { Rounded, } \\
\text { conical }\end{array}$ & $4-6$ & $0.5-1$ & - & - & $\begin{array}{l}\text { JQ712606 } \\
\text { JQ347234 }\end{array}$ & 635 & $\begin{array}{l}\text { CZ } \\
\text { Velký Tisý }\end{array}$ \\
\hline P0A & $\begin{array}{l}\text { Shortly } \\
\text { attenuated }\end{array}$ & $\begin{array}{l}\text { Rounded, } \\
\text { conical }\end{array}$ & $4-5$ & $0.5-1$ & - & - & $\begin{array}{l}\text { JQ712603 } \\
\text { JQ347231 }\end{array}$ & 642 & $\begin{array}{l}\text { CZ } \\
\text { Tovačov }\end{array}$ \\
\hline P001 & $\begin{array}{l}\text { Shortly } \\
\text { attenuated }\end{array}$ & $\begin{array}{l}\text { Rounded, } \\
\text { conical }\end{array}$ & $4-5$ & $0.5-1$ & - & - & $\begin{array}{l}\text { JQ712611 } \\
\text { JQ347239 }\end{array}$ & 644 & $\begin{array}{l}\text { CZ } \\
\text { Záhlinice } 2\end{array}$ \\
\hline P010 & $\begin{array}{l}\text { Shortly } \\
\text { attenuated }\end{array}$ & $\begin{array}{l}\text { Rounded, } \\
\text { conical }\end{array}$ & $4-6$ & $0.3-1$ & - & - & $\begin{array}{l}\text { JQ712613 } \\
\text { JQ347241 }\end{array}$ & 642 & $\begin{array}{l}\text { CZ } \\
\text { Chropyně }\end{array}$ \\
\hline \multicolumn{10}{|c|}{ M. vaginatus } \\
\hline P006 & Attenuated & $\begin{array}{l}\text { Rounded, } \\
\text { conical, } \\
\text { capitate }\end{array}$ & $6-7$ & $0.5-1$ & + & + & $\begin{array}{l}\text { JQ712615 } \\
\text { JQ347243 }\end{array}$ & 566 & $\begin{array}{l}\text { CZ } \\
\text { Obora }\end{array}$ \\
\hline P0R1 & Attenuated & $\begin{array}{l}\text { Rounded, } \\
\text { conical, } \\
\text { capitate }\end{array}$ & $6-7$ & $0.3-1$ & + & + & $\begin{array}{l}\text { JQ712610 } \\
\text { JQ347238 }\end{array}$ & 557 & $\begin{array}{l}\text { CZ } \\
\text { Buková }\end{array}$ \\
\hline P09 & Attenuated & $\begin{array}{l}\text { Rounded, } \\
\text { conical, } \\
\text { capitate }\end{array}$ & $5-7$ & $0.5-1$ & + & + & $\begin{array}{l}\text { JQ712605 } \\
\text { JQ347233 }\end{array}$ & 553 & $\begin{array}{l}\text { CZ } \\
\text { Rožmberk }\end{array}$ \\
\hline P0B & Attenuated & $\begin{array}{l}\text { Rounded, } \\
\text { conical, } \\
\text { capitate }\end{array}$ & $6-7$ & $0.5-1$ & + & + & $\begin{array}{l}\text { JQ712609 } \\
\text { JQ347237 }\end{array}$ & 577 & $\begin{array}{l}\text { CZ } \\
\text { Horní Ves }\end{array}$ \\
\hline $\mathrm{P} 0 \mathrm{C}$ & Attenuated & $\begin{array}{l}\text { Rounded, } \\
\text { conical, } \\
\text { capitate }\end{array}$ & $6-7$ & $0.5-1$ & + & + & $\begin{array}{l}\text { JQ712601 } \\
\text { JQ347229 }\end{array}$ & 581 & $\begin{array}{l}\text { CZ } \\
\text { Bezedník }\end{array}$ \\
\hline \multicolumn{10}{|c|}{ G. pseudacutissimum } \\
\hline P004 & $\begin{array}{l}\text { Not atte- } \\
\text { nuated }\end{array}$ & $\begin{array}{l}\text { Rounded, } \\
\text { pointed }\end{array}$ & $1.5-2$ & $1.5-3$ & - & - & $\begin{array}{l}\text { JQ712617 } \\
\text { JQ347245 }\end{array}$ & 447 & $\begin{array}{l}\text { I } \\
\text { Lake Mon- } \\
\text { bino }\end{array}$ \\
\hline
\end{tabular}


Table 1 Cont.

\begin{tabular}{|c|c|c|c|c|c|c|c|c|c|}
\hline $\mathrm{P} 005$ & $\begin{array}{l}\text { Not atte- } \\
\text { nuated }\end{array}$ & $\begin{array}{l}\text { Rounded, } \\
\text { pointed }\end{array}$ & $1.5-2$ & $1.5-3$ & - & - & $\begin{array}{l}\text { JQ712608 } \\
\text { JQ347236 }\end{array}$ & 451 & $\begin{array}{l}\text { I } \\
\text { Lake Mon- } \\
\text { bino }\end{array}$ \\
\hline P03 & $\begin{array}{l}\text { Not atte- } \\
\text { nuated }\end{array}$ & $\begin{array}{l}\text { Rounded, } \\
\text { pointed }\end{array}$ & $1.5-2$ & $1.5-3$ & - & - & $\begin{array}{l}\text { JQ712614 } \\
\text { JQ347242 }\end{array}$ & 461 & $\begin{array}{l}\text { I } \\
\text { Lake Tovel }\end{array}$ \\
\hline \multicolumn{10}{|c|}{ G. carotinosum } \\
\hline P013 & $\begin{array}{l}\text { Not atte- } \\
\text { nuated }\end{array}$ & $\begin{array}{l}\text { Rounded, } \\
\text { pointed }\end{array}$ & $1.5-2$ & $1.5-3$ & - & - & $\begin{array}{l}\text { JQ712598 } \\
\text { JQ347226 }\end{array}$ & 477 & $\begin{array}{l}\text { A } \\
\text { Lake Unter- } \\
\text { see Lunz }\end{array}$ \\
\hline P014 & $\begin{array}{l}\text { Attenuated, } \\
\text { bent, screw- } \\
\text {-like }\end{array}$ & $\begin{array}{l}\text { Rounded, } \\
\text { capitate }\end{array}$ & $2-3$ & $1.5-3$ & - & - & $\begin{array}{l}\text { JQ712602 } \\
\text { JQ347230 }\end{array}$ & 493 & $\begin{array}{l}\text { I } \\
\text { Lake Mon- } \\
\text { bino }\end{array}$ \\
\hline P017 & $\begin{array}{l}\text { Attenuated, } \\
\text { bent, screw- } \\
\text {-like }\end{array}$ & $\begin{array}{l}\text { Rounded, } \\
\text { capitate }\end{array}$ & $2-2.5$ & $1.5-3$ & - & - & $\begin{array}{l}\text { JQ712599 } \\
\text { JQ347227 }\end{array}$ & 491 & $\begin{array}{l}\text { I } \\
\text { Lake Tovel }\end{array}$ \\
\hline
\end{tabular}

in the Pseudanabaenaceae sister to Leptolyngbya sensu stricto (Fig. 40, clade E). Nodosilinea (Fig. 40 , clade F) is part of a group of strains that were recently described as a new genus (PERKERson et al. 2011).

Analyses of secondary structures in 16S-23S ITS regions (size 447-645 bp) demonstrated both similarity and heterogenity in D1D1' and Box-B helices of Ph. autumnale, $P h$. formosum, M. vaginatus, G. carotinosum, $G$. pseduacutissimum and G. splendidum. Basal parts of all D1-D1' helices in Phormidium and Microcoleus were formed by identical 5 bp basal helices (5'-GACCA-UGGUC-3'), followed by a unilateral bulge on the 3' side (Figs 4148). Generally, secondary structures of D1-D1' helices of $P h$. autumnale, $P h$. formosum and $M$. vaginatus were also similar in the formation of a large terminal loop (Figs 41-48). This is also consistent with our observations of this structure in isolates from desert soils. The region which was variable in the Phormidiaceae clade was the central helix, which contained various and differing small bilateral and unilateral bulges (Figs 41-48). D1-D1'helices of Ph. autumnale, Phormidium formosa and Microcoleus vaginatus were strikingly similar in structure, demonstrating a close phylogenetic relationship between the three taxa (Figs 41-48). Secondary structure of the D1-D1' helices in Ph. formosum demonstrated two lineages. One represented by strains P0010 and P07 (isolated from South Bohemia, Fig. 47) and the second represented by strains P00, P010, P001 (isolated from Central Moravia, Fig. 48), a result consistent with the 16S rRNA phylogeny
(Fig. 40).

The genus Geitlerinema was quite variable in structure of D1-D1'. G. carotinosum (strain P013 isolated from Lunzer Untersee) differed in structure (Fig. 49) from G. pseudoacutissimum, in which D1-D1' helices demonstrated two lineages (Fig. 50-51). However, both species did have the typical 5'-GACCU-AGGUC-3' basal helix characteristic of most cyanobacteria. Both strains of G. splendidum had an identical D1-D1' helix, but these structures were very unique. They lacked the 3'-unilateral bulge found in almost all D1-D1' helices in prokaryotes (Fig. 52). Furthermore, they had a small branch on the 3' side of the central helix (Fig. 53).

Analysis of secondary structures in Box-B helices demonstrated a pattern similar to that obsrved for the D1-D1'helices. All lineages had a conserved basal helix with sequence 5'CAGCA-UGCUG-3'. M. vaginatus generally had longer helices than Ph. autumnale (Fig. 5459). Dissimilarity was evident in the terminal loops, which varied in size and sequence. We found that structures of strains of $M$. vaginatus isolated from Central Moravia were different from those originating from Bohemia. We found some difference between strains of $P$. formosum originating from Bohemia (Fig. 60) and those isolated from Moravia (Fig. 61). Box-B helices differed widely among studied species of Geitlerinema. Two structures of Box-B helices were found in G. pseudoacutissimum but they differed only by one base (Fig. 62-63). The structures of Box-B helices in all three species of Geitlerinema were different (Fig. 62-65). 


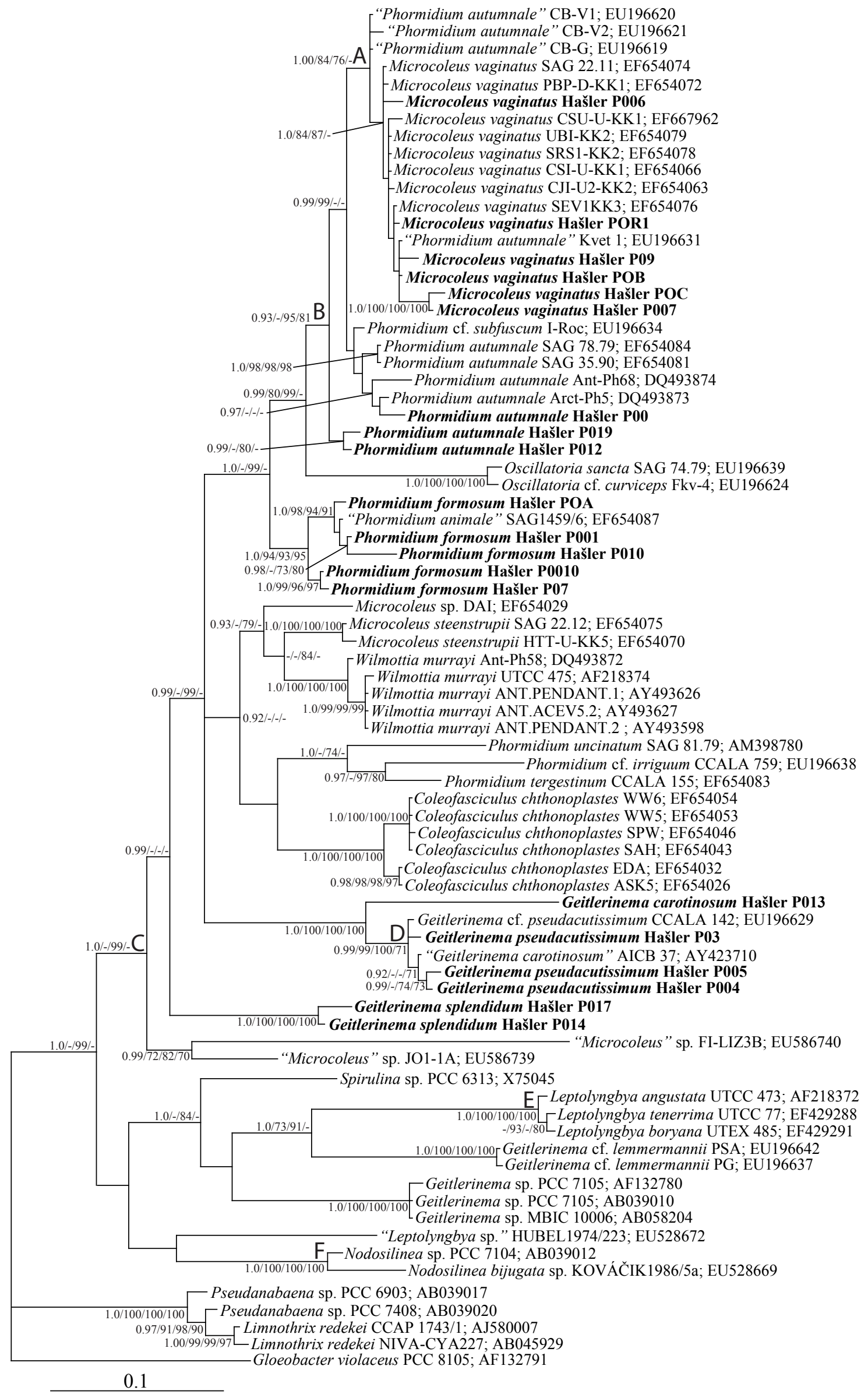




\section{Discussion}

\section{Morphological variability}

We studied morphological variability of filamentous cyanobacteria from the families Phormidiaceae (Phormidium, Microcoleus) and Pseudanabaenaceae (Geitlerinema), which were collected and isolated from the bottom sediments. The distribution of epipelic species has been found to be influenced primarily by sediment quality (HAŠLER et al. 2008). The proportion of fine mud tends to be higher at more eutrophic sites, sandy sediments are characteristic for oligo/dystrophic sites. Muddy or sandy-muddy sediments were inhabited by $P h$. autumnale [Agardh] Trevisan ex Gomont, Ph. formosum (Bory ex Gomont) Anagnostidis et KomÁreK, $M$. vaginatus Gomont ex Gomont and G. splendidum (Greville ex Gomont) Anagnostidis. Sandy sediments were inhabited by $G$. carotinosum (Geitler) Anagnostidis and G. pseudacutissimum (Geitler) Anagnostidis.

Some of the species, Phormidium autumnale and Microcoleus vaginatus, seem to be widely distributed among sampling sites and exhibit overlapping morphological variation. A typical feature of $M$. vaginatus, fasciculate filaments, was consistently observed except in strain P007, which kept a single trichome per filament mode of life in culture. The similarity between $P h$. autumnale and $M$. vaginatus was first discussed by Drouet (1962). He considered Ph. autumnale as a special single filament stage (ecophene) of $M$. vaginatus. The author studied eleven Phormidium-like species (Lyngbya aerugineocaerulea, Ph. autumnale, Ph. favosum, Ph. incrustanum, Ph. setchellianum, Ph. subsalsum, Ph. toficola, Ph. umbilicatum, Ph. uncinatum, Oscillatoria amoena, Os. beggiatoiformis) and postulated that all of them represented natural variability of $M$. vaginatus under different ecological conditions. Recent studies on $P h$. autumnale and $M$. vaginatus have not supported Drouet's opinion (e.g. Casamatta et al. 2005; Siegesmund et al. 2008). Our epipelic strains of $M$. vaginatus showed a narrow morphological variability under laboratory conditions in contrast to descriptions by Drouet (1962) or KomÁREK \& Anagnostidis (2005). The strain P006 was the most representative of epipelic Microcoleus and we consider this strain as epitypic. Ph. autumnale did not exhibit high morphological variability in contrast to previous reports (e.g. GoMONT 1888; GeItLer 1932; Desikachary 1959; Starmach 1966; KONDRATEVA 1968; KOMÁREK 1972; ANAGNOSTIDIS $\&$ KOMÁREK 1988, 2005). Cells were usually wider than long and granulation at cross-walls was fine. The single trichome per filament mode of life was typical. However, old cultures formed flat leathery mats. Ph. formosum represents Phormidium group No. III (following the classification published by KomÁreK \& ANAGNostidis 2005; p. 423, fig. 602). All strains were characterized by shortly narrowed and bent trichome ends with conically-attenuated or rounded apical cells without calyptra. $P h$. formosum shows similarity to another species, e.g. Ph. animale, which belongs to group No II, having gradually narrowed trichome ends in contrast to $P h$. formosum. Our strains of $P h$. formosum and strain $P h$. animale SAG 1459-6 (identical strains: CCAP 1459/6; UTEX 1309) were placed in the same cluster. Ph. animale was isolated before 1972 and morphology has been influenced by long-term cultivation. However, it seems to be similar to our epipelic strains of $P h$. formosum. With respect to similar morphology and position in the same cluster, we conclude that the strain of $P h$. animale should be referred to as $P h$. formosum in future studies. In the case of Ph. formosum/ Ph. animale morphological features may be insufficient to separate them as the key diagnostic feature (long vs. short trichome attenuation) appears variable.

Members of the genus Geitlerinema were originally described within the genus Phormidium. However, morphology, ultrastructure and physiology differ significantly (ANAGNOSTiDIS \& KomÁreK 1988; AnAgnostidis 1989). We isolated two strains of G. splendidium with low morphological variability in contrast to variation described previously (e.g. AnAGNOSTIDIs 1989). We hadoccasion tostudy populations of G. carotinosum quite close to the type locality (Austria, Lunz am

Fig. 40. Phylogram (Consensus Bayesian tree) based on 16S rRNA sequences (size $\sim 1000$ bp) originated from 20 strains of epipelic cyanobacteria (in bold). Bootstrap values are shown (from left to right) as follows: posterior probabilities $\geq 0.9$ and for $\geq 70 \%$ minimum evolution, maximum parsimony, maximum likelihood. Sequences from GenBank which appear to us to be misidentified are in quotation marks. 

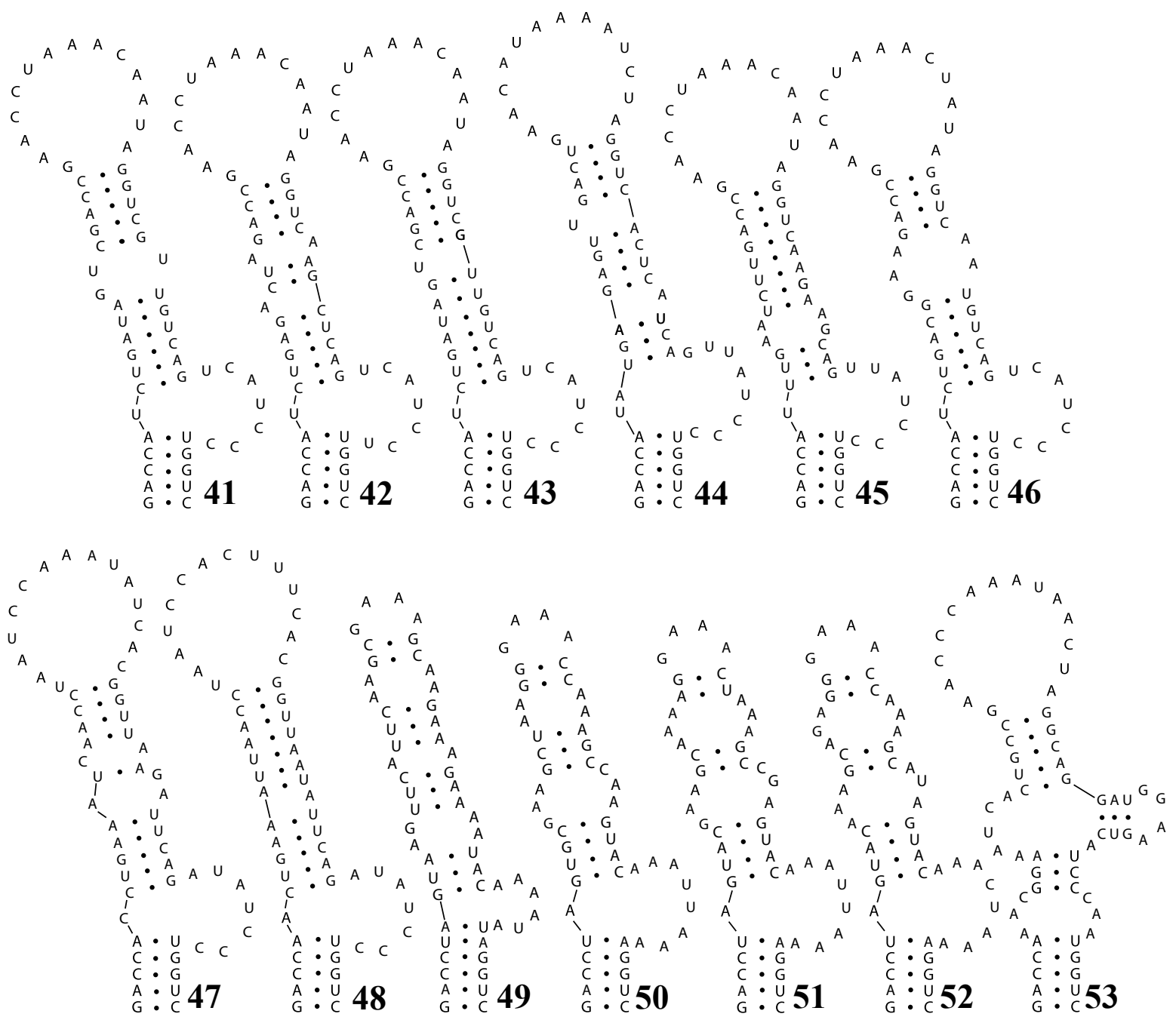

Figs 41-53. ITS secondary structures of D1-D1' helices: (41-43) M. vaginatus, (41) strain P006, (42) strain P09, P007, (43) strain P0B, 0C, P0R1; (44-46) Ph. autumnale, (44) strain P00, (45) strain P019, (46) strain P012; (47-48) Ph. formosum, (47) strain P0010, strain P07, (48) strain P0A, P010, P001; (49) G. carotinosum, strain P013; (50-52) G. pseudacutissimum, (50) strain P03, (51) strain P005, (52) strain P004; (53) G. splendidum, strain P014 and P017.

See, Lake Untersee, strain P013). The species was originally described as Oscillatoria carotinosa (Geitler 1956), later combined as Phormidium carotinosum, subg. Geitlerinema (ANAGNostidis \& KomÁreK 1988). The diagnostic feature of $G$. carotinosum, carotenoid granules, was found in G. pseudoacutissimum as well. Morphology of both species is very similar. However, from our study it seems that trichome ends and type of thallus differ. While G. pseudoacutissimum from Italy formed fascicles and resembled Microcoleus-like thalli, G. carotinosum from Austria created single filaments. Trichome ends of G. carotinosum were usually rounded in contrast to G. pseudoacutissimum with conical apical cells. However, separation of these two taxa based on type/shape of apical cells can be a fairly subjective decision if used as a sole criterion.

In summary, it seems to be rather characteristic that within species, epipelic populations within this study are morphologically very similar, and consequently populations from different ponds and lakes can be reliably placed within the same species. We tried to verify this hypothesis using molecular methods (see below).

\section{S rRNA and secondary structures of $16 \mathrm{~S}-23 \mathrm{~S}$ ITS}

Molecular data for the epipelic species under study were congruent with morphology. However the autecology and distribution of individual species shows the patterns discussed below.

Numerous papers focusing on phylogeny of Phormidium-like taxa have been published during 

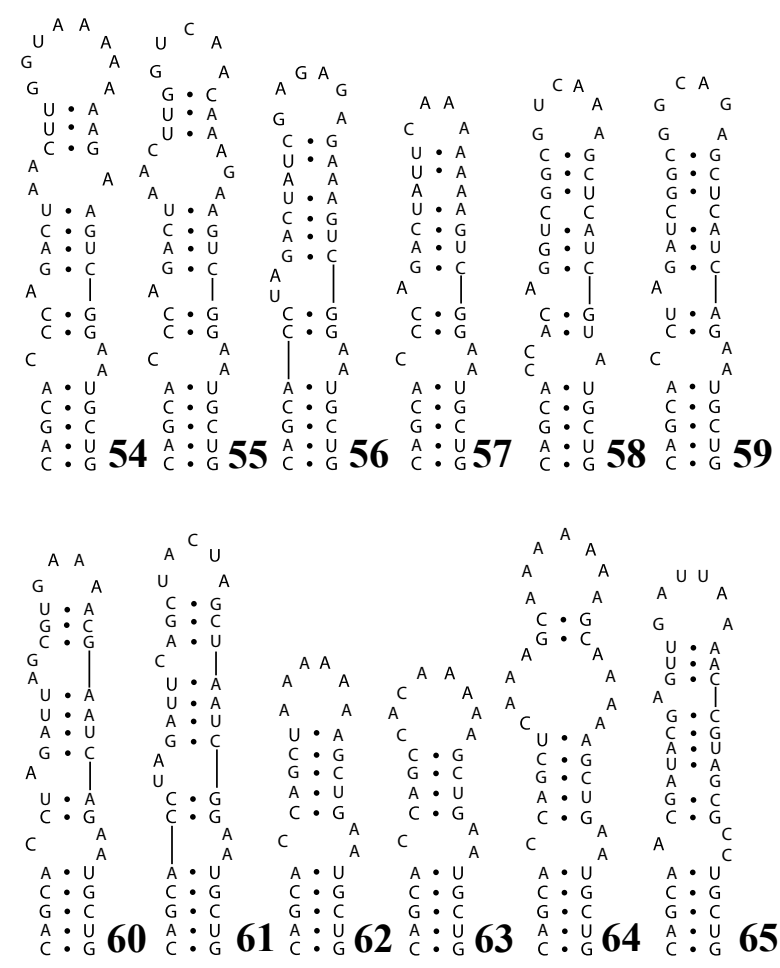

Figs 54-65. ITS secondary structures of Box B helices: (5456) M. vaginatus, (54) strain $\mathrm{P} 006,(55)$ strain $\mathrm{P} 0 \mathrm{~B}, \mathrm{P} 0 \mathrm{C},(56)$ strain P09, P007; (57-59) Ph. autumnale, (57) strain P00, (58) strain P019, (59) strain P012; (60-61) Ph. formosum, (60) strain P0010, (61) strain P0A, P010, P001; (62-63) G. pseudacutissimum, (62) strain P03, (63) strain P004, P005; (64) G. carotinosum, strain P013; (65) G. splendidum, strain P014, P017.

the last decade (e.g. Boyer et al. 2002; MARQUARDT \& Palinska 2007; Palinska \& Marquardt 2008; SIEGESMUND et al. 2008). The majority of authors considered the $M$. vaginatus $-P h$. autumnale complex as polyphyletic, although a high degree of morphological and genetic similarity between the two taxa was found. Important diacritical features overlap (trichome structure, cell dimensions, successive cell division, presence of calyptrae and sheaths, autecology). Analysis of the 16S rRNA gene presented here confirmed the relationship between $M$. vaginatus and $P h$. autumnale recorded previously (SIEGESMUND et al. 2008). A number of workers have noted an 11 bp insert in the 16S rRNA gene (bp 423-433) of M. vaginatus (GARCIA-PICHEL et al. 2001; BOYER et al. 2002; SiEgesmund et al. 2008), and this has been identified as an important synapomorphic feature defining the species. It was surprising to find this marker in our aquatic, epipelic strains, as $M$. vaginatus has been thought to be a soil species in arid soils in the past. Both phylogenetic analysis and the presence of the 11 bp insert distinguished all strains of $M$. vaginatus from Ph. autumnale. M. vaginatus $\mathrm{P} 007$ was morphologically similar to $P$. autumnale and was identified by us as that taxon at first due to its narrower trichome width. In previous studies, $M$. vaginatus was recorded as cosmopolitan, occurring mainly in subaerophytic habitats, soils, moist walls, stones, etc. (e.g. Garcia-Pichel et al. 2001; KomÁreK \& ANAGNOSTIDIS 2005). Our epipelic strains from the Czech Republic clustered together with desert soil strains from the USA (Boyer et al. 2002; Siegesmund et al. 2008). It seems possible that cryptic diversity is present in the clade we currently call $M$. vaginatus, and this diversity is not resolved in the 16S rRNA phylogeny. Morphological differences between strains are evident in our work (Figs 1-8). More detailed study of these aquatic strains (ITS, rbcL, physiology) may allow taxonomic recognition of these strains in the future. Secondary structures of 16S-23S ITS regions were different in epipelic and desert soil strains, the highest variation being found in Box-B helices (cf. Siegesmund et al. 2008; fig. 4). We conclude that differences in $16 \mathrm{~S}-23 \mathrm{~S}$ ITS regions show at least two lineages, one adapted for short periods of desiccation in contrast to a second lineage adapted for long hot periods. In general, genetic variation in the ITS region seems to be a useful feature for distinguishing populations of cyanobacteria with respect to geographical and habitat preferences.

On the other hand our results support the purported cosmopolitanism of Ph. autumnale. Comte et al. (2007) did not find any genetic or morphological differences between Arctic and Antarctic Phormidium-like strains, and their sequences belong to the same clade as our epipelic strain $\mathrm{P} 00$. We postulate that one worldwidedistributed genotype might exist, which cooccurs with genotypes adapted for particular geographical and environmental conditions, as in the case of genetically different strains Hašler P012 and P019. Secondary structures in the ITS region are considered as informative (BOYER et al. 2001, 2002; ŘehÁková et al. 2007; Perkerson et al. 2011), and can serve as an additional taxonomic character. As with previously mentioned authors, we did not find high variability in D1-D1' helices, but Box-B helices showed divergent patterns, which corresponded to the topology of our tree. Differences found between clones from Moravia (P00, P010, P001) and Bohemia (P0010 and $\mathrm{P} 07$ ) cannot be explained by ecology, as all 
localities are eutrophic fishponds with large bird colonies causing organic pollution. However the geographical distance between both regions is approximately $400 \mathrm{~km}$ and the ponds belong to different watersheds and geological units.

$P h$. formosum has not been sufficiently studied by molecular methods. Only three sequences of $16 \mathrm{~S}$ rRNA have been submitted to GenBank. Our strains formed a well supported clade with $P h$. animale SAG 1459/6 which may have been misidentified. Secondary structures of Box-B helices in Ph. formosum had a specific pattern, different from $P h$. autumnale and previously described similar filamentous cyanobacteria (cf. SIEGESMUND et al. 2008).

In the firstmolecular studies on Geitlerinema (e.g. Meyers et al. 2007; Bittencourt-Oliveira et al. 2009), the authors did not discuss the position of the genus within the order Oscillatoriales. In a more recent study (and the most thorough on this genus), the authors indicated that Geitlerine$m a$ was polyphyletic, with Geitlerinema sensu stricto (including the freshwater G. splendidum) in the Pseudanabaenaceae (PerKerson et al. 2010). However, their phylogeny included no Microcoleus or Phormidium taxa, and consequently the familial placement of Geitlerinema remains uncertain. Our strains of G. carotinosum, G. pseudacutissimum and G. splendidum were in an uncertain position between the Phormidiaceae and Pseudanabaenaceae. While some Geitlerinema strains were clearly close to Leptolyngbya in the Pseudanabaenaceae, others were sister to the Phormidiaceae (clade containing Microcoleus, Phormidium, Wilmottia and Coleofasciculus). Two problematic strains originally assigned to Microcoleus (FI-LIZ3B and JO1-1A) by BOYER et al. (2002) are certainly not in that species, and this further confuses the placement of our Geitlerinema strains. The most interesting result of our phylogenetic analysis is that our Geitlerinema splendidum strains (Hašler P014, Hašler P017) are sister to the clade that includes the remainder of our Geitlerinema strains (under $2 \mu \mathrm{m}$ in diameter), as well as all of the Oscillatorineae (Phormidiales and Oscillatoriales). Geitlerinema is currently very problematic as it occupies three clades, two between Pseudanabaenaceae (Synechococcineae) and Phormidiaceae (Oscillatorineae) and one clade within the Pseudanabaenaceae. Studies conducted thus far suggest that Geitlerinema has a thylakoid structure belonging to the Pseudanabaenaceae (KoMÁreK \& ANAGNOSTIDIS
2005). More study on the taxa transitional between the two families (indeed between two subclasses - Synechococcineae and Oscillatorineae! - see HoFFMANN et al. 2005) is certainly needed.

We suggest the revision of the genus Geitlerinema based on material collected from more localities and ecological conditions. Our data show that the genus is not a monophyletic group. This would certainly be consistent with the conclusions of Perkerson et al. (2010) who looked at more putative Geitlerinema than us. Sequences of 16S rRNA from G. carotinosum and G. pseudacutissimum confirmed the validity of recognizing these as separate species. Description of both species based on morphology is almost identical (KoMÁreK \& ANAGNOStidis 2005). However, both species are clearly separated with strong bootstrap support. This finding is supported by analysis of secondary structures in D1-D1' and Box-B helices. It seems that G. carotinosum has been observed only in the type locality and connected lakes in Lunz am See. By contrast, G. pseudacutissimum is known from the Czech Republic (Lužnice River, strain CCALA 142) and from Italy (Lakes Tovel and Monbino). Despite some limitation (number of strains under study) we do not agree with WiLlame et al. (2006) that G. splendidum and G. carotinosum are closely related. Our results are supported by differences in secondary structures in ITS and have a high bootstrap support.

This study showed that for a number of species good agreement between morphology and phylogeny existed at the species level. $M$. vaginatus, $P$. autumnale, $P$. formosum, $G$. pseudoacutissimum, and G. carotinosum all formed monophyletic groups consistent with their morphology. What was surprising was that aquatic members of the $M$. vaginatus clade were found, and these were fairly indistinguishable morphologically from $P$. autumnale. These two taxa differ primarily in sheath and filament characteristics, and these are very variable depending on environmental cues. The sheaths tend to disappear in culture, and actually are not very evident in aquatic populations. The fasciculation clear in soil populations of $M$. vaginatus was only weakly expressed in the epipelon. The strong difference in biotopes (desert soil, Czech lakes) suggests separate lineages, but these lineages were not separable by phylogenetic analysis of the 16S rRNA gene sequence. More study of these populations is certainly of interest, 
as it is at the center of the physiological variability possible in multiple populations of a single species, or the alternative, cryptic species within a genus.

Finally, this study shows that taxonomic revision is almost certainly inevitable in the group of taxa currently encompassed in Phormidium and Microcoleus. These two taxa share the same starting point (Gomont 1892). Microcoleus vaginatus has cell division similar to the Oscillatoriaceae, and is very different from the majority of species in the genus which have cell division similar to Phormidiaceae. The type species of Phormidium is $P$. lucidum, which also has cell division closer to Oscillatoriaceae than Phormidiaceae. Thus, the types for both Microcoleus and Phormidium are in the Oscillatoriaceae as presently defined in KomÁreK \& ANAGNostidis (2005), leaving the vast majority of species in both genera needing revision. Phormidium and Microcoleus are also confused, and a recommendation has even been made to retypify Phormidium with $P$. autumnale (KomÁreK \& ANAGNostidis 2005), which would place both types in a highly supported monophyletic clade. Clearly, this problematic group of species, genera, and even families is in need of further study and revision!

\section{Acknowledgements}

This study was supported by grants GACR 206/07/0115, GACR 206/08/0389, IGA UP Agency no. PrF_2012_001, T. Bat'a Foundation, MSM $6198921 \overline{5}$ and NPGZ-M/03-023 from the Ministry of Agriculture of the Czech Republic.

\section{References}

Anagnostidis, K. (1989): Geitlerinema, a new genus of oscillatorialean cyanophytes. $-\mathrm{Pl}$. Syst. Evol. 164: 33-46.

AnAgnostidis, K. \& KomÁreK, J. (1985): Modern approach to the classification system of cyanophytes, 1-Introduction. - Arch. Hydrobiol. Suppl. 71/Algological Studies 38/39: 291-302.

AnAgnostidis, K. \& KomÁreK, J. (1988): Modern approach to the classification system of cyanophytes, 3-Oscillatoriales. - Arch. Hydrobiol. 80/Algological Studies 50-53: 327-472.

Anagnostidis, K. \& KomÁrek, J. (1990): Modern approach to the classification system of Cyanophytes, 5-Stigonematales. Algological Studies 59: 1-73.

Andersen, R.A. (ed.) (2005): Algal culturing technique. - 596 pp., Academic Press, London.

Ashelford, K.E.; Chuzhanova, N.A.; Fry, J.C.; Jones, A.J. \& Weightman, A. (2005): New screening software show that most recent large 16S rRNA gene clone libraries contain chimeras. - Appl. Environ. Microbiol. 71:7724-7736.

Bittencourt-Oliveira, M.C.; Massola JR, N.S.; Hernandez-Marine, M.; Romo, S. \& MourA, A.N. (2007): Taxonomic investigation using DNA fingerprinting in Geitlerinema species (Oscillatoriales, Cyanobacteria). - Phycol. Res. 55: 214221.

Boyer, S.L.; Flechtner, V.R. \& Johansen, J.R. (2001): Is the 16S-23S rRNA internal transcribed spacer region a good tool for use in molecular systematics and population genetics? A case study in cyanobacteria. Mol. Biol. Evol. 18: 1057-1069.

Boyer, S.L.; Johansen, J.L.; Flechtner, V.R. \& Howard, G.L. (2002): Phylogeny and genetic variance in terrestrial Microcoleus (Cyanophyceae) species based on sequence analysis of the 16S rRNA gene and the associated $16 \mathrm{~S}-23 \mathrm{~S}$ ITS region. - J. Phycol. 38: 1222-1235.

Casamatta, D.A.; Johansen, J.R.; VIS, M.L. \& BRoAdWATER, S.T. (2005): Molecular and morphological characterization of ten polar and near-polar strains within the Oscillatoriales (Cyanobacteria). - J. Phycol. 41:421-438.

Castenholz, R.W. (2001): Phylum BX. Cyanobacteria. Oxygenic Photosynthetic Bacteria. - In: Boone, D.R. \& Castenholz, R.W. (eds): Bergey's Manual of Systematic Bacteriology, $2^{\text {nd }}$ Edition. - pp. 473-599, Springer Verlag.

Comte, K.; Š A.; Elster, J. \&KOMÁReK, J. (2007): Relationships between the Arctic and the Antarctic cyanobacteria; three Phormidium-like strains evaluated by a polyphasic approach. - FEMS Microbiol. Ecol. 59: 366-376.

Desikachary, T.V. (1959): Cyanophyta. - 686 pp., Indian Concil of Agricultural Research, 
New Delhi.

Doyle, J.J. \& DoyLe, J.L. (1990): Isolation of plant DNA from fresh tissue. - Focus 12:13-15.

Drouet, F. (1962): Gomont's ecophenes of the blue-green alga Microcoleus vaginatus (Oscillatoriaceae). - Proc. Acad. Nat. Sci. Phila. 114: 191-205.

Elenkin, A.A. (1938): Monographia algarum cyanophycearum aquidulcium et terretrium in finibus URSS inventarum. - 1908 pp., Sumptibus Academiae Scientiarum URSS, Leningrad.

FerRis, M.; RufF-Roberts, A.; Kopczynski, E.; Bateson, M. \& Ward, D. (1996): Enrichment culture and microscopy cenceal diverse thermophilic Synechococcus populations in a single hot spring microbial mat habitat. - Appl. Environ. Microbiol. 62: 1045-1050.

Garcia-Pichel, F.; Prufert-Bebout, L. \& Muyzer, G. (1996): Phenotypic and phylogenetic analyses shows Microcoleus chtonoplastes to be a cosmopolitan cyanobacterium. - Appl. Environ. Microb. 62: 3284-3291.

Garcia-Pichel, F.; Lopez-Cortez, A. \& Nubel, U. (2001): Phylogenetic and morphological diversity of cyanobacteria in soil deserts crusts from the Colorado Plateau. - Appl. Environ. Microb. 67: 1902-1910.

Geitler, L. (1932): Cyanophyceae. - In: RABENHORST, L. (ed.): KryptogamenFlora. - 1196 pp., Akademische Verlagsgesellschaft, Leipzig.

Geitler, L. (1956): Oscillatoria carotinosa n.sp. und O. pseudoacutissima n. sp. Zwei Arten mit lokalisierter Karotinoidbildung. Österr. Bot. Z. 103: 342-345.

Gomont, M. M. (1888): Note sur le genre Phormidium Kützing. - Bull. Soc. France 34: 18-21.

Gomont. M. M. (1892): Monographie des Oscillariées (Nostocacées homocystées). Ann. Sci. nat. Bot., Ser. 15: 263-368, 16 : 91-264.

Hall, T. (2005): BioEdit Sequence Alignment Editor for Windows 95/98/NT/XP. Ibis Therapeutics, A division of Isis Pharmaceuticals, Carlsbad, CA, USA.

HaŠLER, P.; ŠTĚPÁNKOVÁ, J.; ŠPAČKoVÁ, J.; Neustupa, J.; Kitner, M.; Hekera, P.; Veselá, J.; Burian, J. \& PoulíčKová, A. (2008): Epipelic cyanobacteria and algae: a case study from Czech ponds. - Fottea 8: 133-146.

HašLer, P. \& PoulíčKovÁ, A. (2010): Diversity, taxonomy and autoecology of autochotnous epipelic cyanobacteria of the genus Komvophoron (Borziaceae, Oscillatoriales): a study on populations form the Czech Republic and British Isles. - Biologia 65: 7-16.

HofFMAN, L.; KAŠTOVSKÝ, J. \& KoMÁReK, J. (2005): Proposal of cyanobacterial system - 2004. - In: Büdel, B.; Gärdner, G.; Krienitz, L. \& Schagerl, M. (EDS): Cyanoprokaryota. 2. Teil: Oscillatoriales, Süsswasserflora von Mitteleuropa, vol. 19/2. - pp. 657-660, Elsevier, München.

KoMÁREK, J. (1972): Temperaturbedingte morphologische Variabilität bei drei Phormidium-Arten (Cyanophyceae) in Kulturen. - Preslia 44: 293-307.

KomÁREK, J. (1994): Current trends and species delimitation in the cyanoprokaryote taxonomy. - Algological Studies 75: 11-29.

KomÁrek, J. (2003): Problem of the taxonomic category "species" in cyanobacteria. Algological Studies 109: 281-297.

KomÁReK, J. (2010): Recent changes (2008) in cyanobacteria taxonomy based on a combination of molecular background with phenotype and ecological consequences (genus and species concept). Hydrobiologia 639: 245-259.

KomÁreK, J. \& AnAgnostidis, K. (1986): Modern approach to the classification system of cyanophytes, 2-Chroococcales. - Arch. Hydrobiol. 73/Algological Studies 43: 157-226.

KomÁrek, J. \& Anagnostidis, K. (1989): Modern approach to the classification system of Cyanophytes, 4-Nostocales. - Arch. Hydrobiol. Suppl. 82/Algological Studies 56: 247-345.

KomÁReK, J. \& AnAgnostidis, K. (1998): Cyanoprokaryota. 1. Teil: Chroococcales. - In: Ettl, H.; Gärdner, G.; Heying, H. \& Mollenhauer, D (eds): Süsswasserflora von Mitteleuropa, vol. 19/1. - 548 pp., Gustav Fischer, Jena-Stuttgart-LübeckUlm.

KomÁreK, J. \& Anagnostidis, K. (2005): Cyanoprokaryota. 2. Teil: Oscillatoriales. In: BÜdEl B., GÄrdner G., KRIEnitz L. \& Schagerl M. (eds): Süsswasserflora von 
Mitteleuropa, vol. 19/2. - 759 pp., Elsevier, München.

KomÁReK, J. (2011): Introduction to the $18^{\text {th }}$ IAC Symposium in České Budějovice 2010, Czech Republic. Some current problems of modern cyanobacterial taxonomy. - Fottea 11: 1-7.

Kondrateva, N.V. (1968): Sin'o zeleni vodorostli - Cyanophyta [Blue-green algae Cyanophyta]. - 522 pp., Vid. „Naukova dumka“, Kiev, UkrRSR.

Larkin, M.A.; Blackshields, G.; Brown, N.P.; Duenna, R.; McGettigan, P.A.; McWilliam, H.; Valentin, F.; Wallace, I.M.; WILM, A.; LOPEZ, R.; THOMPSON, J.D.; GibBon, T.J. \& HigGins, D.G. (2007): Clustal W and Clustal X version 2.0. Bioinformatics 23:2947-2948.

Marquardt, J. \& Palinska, K.A. (2007): Genotypic and phenotypic diversity of cyanobacteria assigned to the genus Phormidium (Oscillatoriales) from different habitats and geographical sites. Arch. Microbiol. 187: 397-413.

Myers, J.L.; Sekar, R. \& Richardson, L.L. (2007): Molecular detection and ecological significance of the cyanobacterial genera Geitlerinema and Leptolyngbya in black band disease of corals. - Appl. Environ. Microb. 73: 5173-5182.

Palinska, K.A. \& Marquardt, J. (2008): Genotypic and phenotypic analysis of strains assigned to the widespread cyanobacterial morphospecies Phormidium autumnale (Oscillatoriales). - Arch. Microbiol. 189: 325-335.

Perkerson, R.B.; Perkerson, E.A. \& Casamatta, D.A. (2010): Phylogenetic examination of the cyanobacterial genera Geitlerinema and Limnothrix (Pseudanabaenaceae) using 16S rDNA gene sequence data. - Algological Studies 134: 1-16.

Perkerson, R.B.; Johansen, J.R.; Kováčik, L.; BRand, J.; KaštovskÝ, J. \& Casamatta, D.A. (2011): A unique Pseudanabaenalean (Cyanobacteria) genus Nodosilinea gen. nov. based on morphological and molecular data. - J. Phycol. 47: 1397-1412.

PoulíčKová, A.; Hašler, P.; Lysaková, M. \& Spears, B. (2008a): The ecology of freshwater epipelic algae: an update. Phycologia 47: 437-450.

PoulíčKovÁ, A.; ŠPaČKovÁ, J.; Kelly, M.G.;
Duchoslav, M. \& Mann, D.G. (2008b): Ecological variation within Sellaphora species complexes (Bacillariophyceae): specialists or generalists? - Hydrobiologia 614: 373-386.

PoulíčKová, A.; Neustupa, J.; ŠpaČKová, J. \& ŠKaLOUD, P. (2009): Distribution of epipelic diatoms in artificial fishponds along environmental and spatial gradients. Hydrobiologia 624: 81-90.

Rippka, R.; Deruelles, J.; Waterbury， J.B.; Herdman, M. \& Stanier, R.Y. (1979): Generic assignments, strain histories and properties of pure cultures of Cyanobacteria. - J. Gen. Microbiol. 111: 1-61.

Ronquist, F. \& HuELSENBECK, J.P. (2003): MRBAYES 3: Bayesian phylogenetic inference under mixed models. Bioinformatics 19:1572-1574.

Round, F.E. (1953): An investigation of two benthic algal communities in Malham Tam, Yorkshire. - J. Ecol. 41: 174-179.

Round, F.E. (1957): Studies on bottom-living algae in some lakesof the English Lake district. Part I. Some chemical features of the sediments related to algal productivities. - J. Ecol. 45: 133-148.

Round, F.E. (1961): Studies on bottom-living algae in some lakesof the English Lake district. Part V. The seasonal cycles of the Cyanophyceae. - J. Ecol. 49: 31-38.

ŘehÁKovÁ, K.; Johansen, J.R.; CASAMATta, D.A.; Xuesong, L. \& Vincent, J. (2007): Morphological and molecular characterization of selected desert soil cyanobacteria: Three species new to science including Mojavia pulchra gen. et sp. nov. - Phycologia 46: 481-502.

Siegesmund, M.A.; Johansen, J.R.; Karsten, U. \& Friedl, T. (2008): Coleofasciculus gen. nov. (Cyanobacteria): morphological and molecular criteria for revision of the genus Microcoleus Gomont. - J. Phycol. 44:1572-1585.

ŠPAČKOVÁ, J.; HAŠLER, P.; ŠTĚPÁNKOVÁ, J. \& PoulíčKovÁ, A. (2009): Seasonal succession of epipelic algae: a case study on a mesotrophic pond in a temperate climate. - Fottea 9: 121-133.

Staub, R. (1961): Research on physiology of nutrients of the planktonic cyanobacterium Oscillatoria rubescens. - Schweiz. Z. Hydrol. 23: 83-198. 
Stanier, R.Y.; Sistrom, W.R.; Hansen, T.A.; Whitton, B.A.; Castenholz, R.W.; Pfennig, N.; Gorlenko, V.N.; Kondrateva, E.N.; EImhJellen, K.E.; Whittenbury, R.; Gherna, R.L. \& TrüPer, H.G. (1978): Proposal to place the nomenclature of the cyanobacteria (blue-green algae) under the rules of the International Code of Nomenclature of Bacteria. - Int. J. Syst. Bacteriol. 28: 335-336.

Starmach, K. (1966): Cyanophyta-sinice. - 753 pp., PAN, Państw.Wyd.Nauk., Warszawa.

Swofford, D.L. (2001): PAUP*. Phylogenetic analysis using parsimony (*and other methods). Version4. - Sinauer Associates, Sunderland, Massachusetts.

Tamura, K.; Dudley, J.; Nei, M. \& Kumar, S. (2007): MEGA4: Molecular Evolutionary Genetics Analisis (MEGA) software version 4.0. - Mol. Biol. Evol. 24: 15961599.

Willame, R.; Boutte, C.H.; Grubisic, S.; Wilmotte, A.; Komárek, J. \& Hoffmann, L. (2006): Morphological and molecular characterization of planktonic cyanobacteria from Belgium and Luxembourg. - J. Phycol. 42: 1312-1332.

ZuCKer, M. (2003). Mfold web server for nucleic acid folding and hybridization prediction. Nucleic. Acids. Res. 31: 3406-15.

(C) Czech Phycological Society (2012)

Received May 9, 2012

Accepted July 1, 2012 